\title{
PENGARUH DUKUNGAN ORGANISASI TERHADAP KOMITMEN ORGANISASIONAL DAN KINERJA PEGAWAI
}

\author{
Ketut Metria ${ }^{1}$ \\ I Gede Riana ${ }^{2}$ \\ ${ }^{1,2}$ Fakultas Ekonomi dan Bisnis Universitas Udayana (Unud), Bali, Indonesia \\ e-mail: metriaketut@gmail.com
}

\begin{abstract}
ABSTRAK
Penelitian ini bertujuan untuk menganalisis: (1) pengaruh dukungan organisasi terhadap kinerja pegawai, (2) pengaruh dukungan organisasi terhadap komitmen organisasional dan (3) Pengaruh komitmen organisasional terhadap kinerja pegawai. Sebanyak 77 pegawai Dinas Kependudukan dan Pencatatan Sipil Kota Denpasar digunakan sebagai sampel dengan teknik pengambilan sampel yaitu sampling jenuh. Data yang diperoleh dianalisis dengan analisis deskriptif dan SEM-PLS. Hasil penelitian menemukan bahwa dukungan organisasi berpengaruh positif dan signifikan terhadap kinerja pegawai, dengan nilai koefisien sebesar 0,389 dan nilai $t$ statistics sebesar 4,086 (> t kritis 1,96). Pengaruh dukungan organisasi terhadap komitmen organisasional menghasilkan nilai koefisien sebesar 0,634 dan nilai $t$ statistics sebesar 9,091 (>t kritis 1,96) yang berarti signifikan. Selanjutnya komitmen organisasional juga berpengaruh positif signifikan terhadap kinerja pegawai, dengan nilai koefisien sebesar 0,363 dan nilai $\mathrm{t}$ statistics sebesar 4,635 (>t kritis 1,96). Penelitian ini membuktikan bahwa pegawai yang mendapat dukungan dari organisasinya terbukti mampu meningkatkan komitmen organisasional untuk bekerja yang berimplikasi kepada semakin baiknya kinerja yang ditampilkan oleh pegawai Dinas Kependudukan dan Pencatatan Sipil Kota Denpasar.
\end{abstract}

Kata Kunci: dukungan organisasi, komitmen organisasional, kinerja pegawai

\begin{abstract}
This study aims to analyze: (1) influence of organizational support to employee performance, (2) influence of organizational support to organizational commitment and (3) influence organizational commitment to employee performance. A total of 77 employees of the Department of Population and Civil Registration of Denpasar is used as a sample with sampling technique that is saturated sampling. The data obtained were analyzed by descriptive analysis and SEM-PLS. The result of this study found that organizational support had positive and significant effect on employee performance, with coefficient value was 0,389 and $t$ statistics value was 4,086 (> $t$ critical 1,96). The effect of organizational support on organizational commitment resulted in coefficient value of 0.634 and $t$ statistics of 9.091 (> t critical 1.96) which means significant. Furthermore, organizational commitment also has a significant positive effect on employee performance, with coefficient value of 0.363 and t statistics value of 4.635 (>t critical 1.96). This study proves that employees who get support from the organization proved able to increase organizational commitment to work which implies to the better performance displayed by employees of the Department of Population and Civil Registration of Denpasar.
\end{abstract}

Keywords: organizational support, organizational commitment, employee performance 


\section{PENDAHULUAN}

Pelaksanaan otonomi daerah, sebagai kelanjutan dari agenda reformasi politik yang digulirkan tahun 1998, harus diakui belum mampu menghasilkan perbaikan kehidupan yang berarti bagi sebagian besar masyarakat Indonesia. Keinginan masyarakat untuk menikmati pelayanan publik yang efisien, responsif dan akuntabel masih belum sepenuhnya dapat diwujudkan, karena reformasi politik yang digulirkan tidak diikuti dengan upaya peningkatan kualitas pelayanan publik. Berbagai praktik buruk dalam penyelenggaraan pelayanan publik seperti: ketidakpastian pelayanan, pungutan liar, proses yang berbelit-belit, lamanya waktu penyelesaian serta pengabaian hak dan martabat warga pengguna pelayanan, masih amat mudah dijumpai hampir di setiap satuan pelayanan publik (Tjokroamidjojo, 2001:107-108).

Nunik (2001) menyatakan bahwa tingkat kepercayaan masyarakat (publik trust) terhadap organisasi publik mulai menurun. Lebih lanjut dikatakan bahwa pada kebanyakan organisasi publik masih sering dijumpai lebih tingginya proporsi fungsi pengaturan dibanding fungsi layanan. Kondisi ini menuntut dilaksanakannya reformasi yang mengarah pada perbaikan, pembaharuan dan pengembangan pola dan gaya penyelenggaraan pemerintahan yang lebih baik, demokratis, terbuka, efisien, efektif dan akuntabel.

Dinas Kependudukan dan Pencatatan Sipil Kota Denpasar sebagai salah satu satuan kerja perangkat daerah di Kota Denpasar mempunyai tugas, kewajiban dan tanggungjawab membangun pelayanan publik dalam bidang kependudukan dan pencatatan sipil. Dalam memberikan pelayanan kepada masyarakat, Dinas 
Kependudukan dan Pencatatan Sipil Kota Denpasar melayani 14 jenis pelayanan. Namun dalam prakteknya, masih terdapat beberapa pelayanan yang belum dicapai secara maksimal sampai tahun 2016, yaitu permohonan kartu keluarga (KK), kartu tanda penduduk (KTP), akta kelahiran, akta perkawinan dan akta perceraian, seperti terlihat pada Tabel 1.1 berikut

Tabel 1.1

Data Pelayanan Dinas Kependudukan dan Pencatatan Sipil Kota Denpasar Tahun 2016

\begin{tabular}{ccccc}
\hline No & Jenis Layanan & Permohonan masuk & Realisasi & Persentase \\
\hline 1 & KTP & 159.822 & 77.739 & $48 \%$ \\
2 & KK & 49.782 & 42.716 & $85 \%$ \\
3 & Akta Kelahiran & 13718 & 11.386 & $83 \%$ \\
4 & Akta Perkawinan & 3.561 & 3.509 & $98 \%$ \\
5 & Akta Perceraian & 522 & 355 & $68 \%$ \\
\hline
\end{tabular}

Sumber : Dinas Kependudukan dan Pencatatan Sipil Kota Denpasar (2016)

Tabel 1.1 menunjukkan bahwa realisasi data layanan di Dinas Kependudukan dan Pencatatan Sipil Kota Denpasar belum terealisasi seratus persen. Hal ini disebabkan oleh beberapa faktor, salah satunya adalah dukungan organisasi dan komitmen pegawai dalam memberi pelayanan kepada masyarakat. Disinilah peran dukungan organisasi berupa ketersediaan blangko dan alat perekaman KTP elektronik sangat diperlukan guna menunjang kinerja pegawai sehingga mencapai hasil kerja yang maksimal.

Masalah pelayanan akta catatan sipil dan kartu identitas penduduk sudah menjadi perhatian yang sangat mendasar bagi publik khususnya di Kota Denpasar. Karena sampai saat ini masyarakat belum merasa puas terhadap pelayanan yang diberikan, yang berdampak masih ada sebagian masyarakat belum memiliki akta catatan sipil dan kartu identitas penduduk. Masalah ini belum bisa diatasi secara maksimal oleh Dinas Kependudukan dan Pencatatan Sipil Kota Denpasar yang 
disebabkan karena sarana dan prasarana kurang tersedia, sumber daya manusia belum memadai, kurangnya kesadaran bagi pegawai akan tanggungjawabnya.

Menurut Kumorotomo (2005), konsep kinerja organisasi publik setidaknya berkaitan erat dengan efisiensi, efektifitas, keadilan dan daya tanggap. Kinerja menunjukkan kemampuan pegawai dalam melaksanakan dan menyelesaikan tugas untuk mencapai target yang telah ditentukan. Jika hasil pekerjaan seorang pegawai baik dan sesuai dengan prosedur yang telah ditetapkan oleh organisasi maka tujuan dari organisasi akan dapat tercapai. Untuk mencapai kinerja yang baik tentunya harus mempertimbangkan faktor yang mempengaruhi kinerja tersebut. Faktor - faktor yang mempengaruhi kinerja pegawai adalah sikap mental (berupa disiplin kerja, motivasi kerja, etika kerja), pendidikan dan pelatihan, keterampilan, manajemen, tingkat penghasilan, gizi dan kesehatan, jaminan sosial, lingkungan dan iklim kerja, sarana produksi, teknologi dan kesempatan berprestasi (Nitisemito,2000).

Beberapa penelitian yang menunjukkan bahwa kinerja dapat dipengaruhi oleh beberapa faktor. Penelitian Hong (2012), menunjukkan bahwa karyawan bersedia untuk tinggal dan mengabdikan diri untuk mencapai tujuan pekerjaan karena mereka memiliki nilai yang sama dan tujuan dalam organisasi, produktifitas mereka akan meningkat dan begitu juga prestai kerja. Sementara itu, atasan harus memberikan penghargaan yang sesuai kepada bawahan ketika mereka mencapai tujuan pekerjaannya.

Komitmen organisasi adalah keinginan kuat untuk tetap sebagai anggota organisasi tertentu, keinginan untuk berusaha keras sesuai dengan keinginan 
organisasi, serta keyakinan tertentu dan penerimaan nilai dan tujuan organisasi. Dengan kata lain merupakan sikap yang merefleksikan loyalitas karyawan pada organisasi dan proses berkelanjutan dimana anggota organisasi mengekspresikan perhatiannya terhadap organisasi dan keberhasilan serta kemajuan yang berkelanjutan (Luthan, 2006). Komitmen organisasional yang tinggi akan menghasilkan performa kerja yang baik dan rendahnya tingkat absensi. Komitmen organisasional mendorong karyawan untuk mempertahankan pekerjaannya dan menunjukkan hasil yang seharusnya (Greenberg, 1996).

Penelitian Eisenberger et al. (1990) yang menyatakan bahwa karyawan yang mendapatkan dukungan dari organisasinya, cenderung tidak akan mencari pekerjaan lain atau tidak akan menerima tawaran pekerjaan dari perusahaan lain. Pekerja akan merasakan mendapat dukungan dari organisasinya saat imbalan yang diberikan dirasakan adil, mereka memiliki suara dalam keputusan dan saat mereka melihat atasannya bersifat suportif. Dukungan organisasi dipandang sangat penting bagi perilaku pekerjanya, dukungan itu bisa berupa bentuk perhatian dari pimpinan kepada bawahannya dan juga bisa berupa sarana dan prasarana yang memadai di dalam menunjang kinerja pegawainya.

Persepsi dukungan organisasi mengacu pada persepsi karyawan mengenai sejauh mana organisasi menilai kontribusi, memberi dukungan, dan peduli pada kesejahteraan mereka (Rhoades and Eisenberger, 2002). Dukungan organisasi dipandang sangat penting bagi perilaku pekerjanya. Organisasi memiliki kewajiban untuk mengembangkan suatu iklim yang mendukung orientasi konsumen. Gronroos (1990) menemukan bahwa dukungan organisasi dan 
manajemen akan meningkatkan motivasi perilaku orientasi pelanggan dari para pekerjanya. Meglino et al. (1989) mengemukakan bahwa individu yang mempunyai nilai-nilai yang sama dengan organisasi, maka mereka akan mudah berinteraksi secara efisien dengan sistem nilai organisasi, mengurangi ketidakpastian, dan konflik serta meningkatkan kepuasan dan meningkatkan kinerja.

Susskind et al. (2000) berpendapat bahwa dukungan perusahaan dapat digunakan untuk meningkatkan motivasi pekerja yang berhubungan dengan pelanggan, sehingga dapat dikatakan variabel dukungan perusahaan dapat berpengaruh positif terhadap motivasi pekerja. Dukungan organisasi yang dikembangkan oleh Susskind et al. (2000) terdiri dari 3 item yaitu penghargaan terhadap nilai, kesediaan perusahaan untuk membantu dan kepedulian perusahaan. Mathis et al. (2001:84) menyatakan dukungan organisasi sebagai dukungan yang diberikan organisasi kepada pegawai berupa pelatihan, peralatan, harapan-harapan dan tim kerja yang produktif.

Moenir (1992:119) mengemukakan bahwa, sarana adalah segala jenis peralatan, perlengkapan kerja dan fasilitas yang berfungsi sebagai alat utama/pembantu dalam pelaksanaan pekerjaan, dan juga dalam rangka kepentingan yang sedang berhubungan dengan organisasi kerja. Dukungan positif pimpinan dan segenap pegawai akan menciptakan situasi kerja yang kondusif. Dengan mendapatkan dukungan tersebut kinerja anggota akan terpacu untuk lebih baik. Selain itu dukungan juga memunculkan semangat para tim pekerja sehingga 
mereka dapat saling mempercayai dan saling membantu serta adanya hubungan baik antar pekerja di dalam lingkungan kerja (Shaam et al., 1999).

Organisasi perlu memperlakukan karyawannya secara manusiawi, karena karyawan bukanlah alat yang hanya dituntut untuk bekerja secara optimal saja, tetapi karyawan juga harus diperhatikan kebutuhan - kebutuhannya, seperti kesejahteraan, penghargaan, pengakuan dan kesempatan untuk berkembang. Karyawan akan mempunyai persepsi ketika apa yang mereka berikan tidak sebanding dengan apa yang diterima, akibatnya karyawan akan menjadi malas dan sering absen. Karyawan yang merasa bahwa organisasi ditempatnya bekerja memberikan dukungan, menghargai hasil kerja dan peduli akan kesejahteraan karyawan, maka karyawan akan cenderung lebih berkomitmen terhadap organisasinya (Rhoades dan Eisenberger, 2002).

Hal ini didukung juga oleh hasil penelitian yang dilakukan oleh Celep dan Yilmazturk (2012) yang menyatakan bahwa, terdapat hubungan yang positif signifikan antara dukungan organisasi terhadap komitmen organisasional. Semakin tinggi dukungan yang dirasakan karyawan maka komitmen karyawan terhadap organisasinya akan semakin kuat. Susskind et al. (2000) berpendapat bahwa, dukungan organisasi dapat digunakan untuk meningkatkan motivasi pekerja yang berhubungan dengan pelanggan, sehingga dapat dikatakan variabel dukungan organisasi dapat berpengaruh positif terhadap motivasi pekerja. 
Menurut Eisenberger (dalam Wann Yih dan Htaik, 2011) menyatakan bahwa karyawan menganggap pekerjaan mereka sebagai hubungan timbal balik yang mencerminkan ketergantungan relatif yang melebihi kontrak formal dengan organisasinya yang berarti bahwa karyawan dan organisasi terlibat dalam hubungan timbal balik. Odunlami et al. (2014) menyatakan bahwa dukungan manajemen memiliki pengaruh yang signifikan terhadap kinerja karyawan. Penelitian yang dilakukan oleh Arshadi et al. (2013) menunjukkan persepsi dukungan organisasi berpengaruh terhadap kinerja. Penelitian lainnya dilakukan oleh Susmiati dkk (2015) dan Afzali et al. (2014) menunjukkan bahwa persepsi dukungan organisasi berpengaruh terhadap kinerja. Selanjutnya Silviana Mursidta (2017) pada PT. Varia Usaha Beton Gresik menyatakan bahwa persepsi dukungan organisasi berpengaruh positif signifikan terhadap kinerja karyawan.

Selain itu para peneliti juga menambahkan bahwa pegawai yang didukung oleh organisasi akan memberikan timbal baliknya dan menurunkan ketidakseimbangan dalam hubungan tersebut. Sebelumnya telah dilakukan penelitian yang mendukung bahwa dukungan organisasi memiliki hubungan positif terhadap kinerja yaitu Kuncoro (2009) yang mengatakan bahwa dukungan usaha berpengaruh terhadap kinerja. Apabila dukungan organisasi ditingkatkan maka kinerja pegawai juga akan mengalami peningkatan. Berdasarkan pada uraian di atas maka peneliti mengembangkan hipotesis yang terkait dengan dukungan organisasi sebagai berikut:

$\mathrm{H}_{1}$ : Dukungan organisasi berpengaruh positif dan signifikan terhadap kinerja pegawai. 
Karyawan menginterpretasikan dukungan dari organisasi di mana mereka bekerja sebagai perwujudan komitmen dari organisasi tersebut terhadap mereka dan akan mengembalikannya dengan meningkatkan komitmen mereka terhadap organisasi (Aube et al. 2007). Hasil penelitian Wahyu (2011), menunjukkan bahwa persepsi dukungan organisasi berhubungan dan mempengaruhi komitmen organisasi. Tumwesigye (2010) menyatakan bahwa persepsi dukungan organisasi berpengaruh positif terhadap komitmen organisasional. Gupta et al. (2010) memperoleh hasil bahwa persepsi dukungan organisasi berpengaruh positif terhadap komitmen organisasional.

Chiang et al. (2011) dalam penelitian menemukan bahwa dukungan organisasi berpengaruh positif signifikan terhadap komitmen organisasi. Temuan serupa oleh Dewi dan Rahyuda (2015) juga menyatakan bahwa dukungan organisasi berpengaruh positif dan signifikan terhadap komitmen organisasi. Berdasarkan pada uraian di atas maka peneliti mengembangkan hipotesis yang terkait dengan dukungan organisasi sebagai berikut:

$\mathrm{H}_{2}$ : dukungan organisasi berpengaruh positif dan signifikan terhadap komitmen organisasional

Irefin dan Mechanic (2014) juga menemukan adanya hubungan yang cukup tinggi antara komitmen karyawan dengan kinerja organisasi pada Coca Cola Nigeria Limited. Selanjutnya Lotunani et al. (2014) menemukan bahwa komitmen berhubungan positif dan signifikan terhadap kinerja pegawai negeri. Murgianto et al. (2016) menemukan bahwa komitmen memiliki hubungan 
yang signifikan terhadap kinerja pegawai.

Chen dan Francesco (2003) meneliti tentang hubungan tiga komponen komitmen dengan in role performance dan $O C B$, dengan hasil bahwa komitmen efektif berhubungan positif dengan in role performance dan $O C B$, sedangkan komitmen kontinyu tidak terkait dengan in role performance dan komitmen normatif memoderasi hubungan antara komitmen efektif dan in role performance dan $O C B$. Terwujudnya kinerja karyawan yang baik akan sangat tergantung dari bagaimana komitmen mereka terhadap organisasi. Berdasarkan pada uraian di atas maka peneliti mengembangkan hipotesis yang terkait dengan dukungan organisasi sebagai berikut:

$\mathrm{H}_{3}$ : Komitmen organisasional berpengaruh positif dan signifikan terhadap kinerja pegawai.

Berdasarkan pembahasan latar belakang dan penelusuran terhadap sejumlah temuan studi empiris, maka kerangka konseptualnya dapat disusun sebagai berikut:

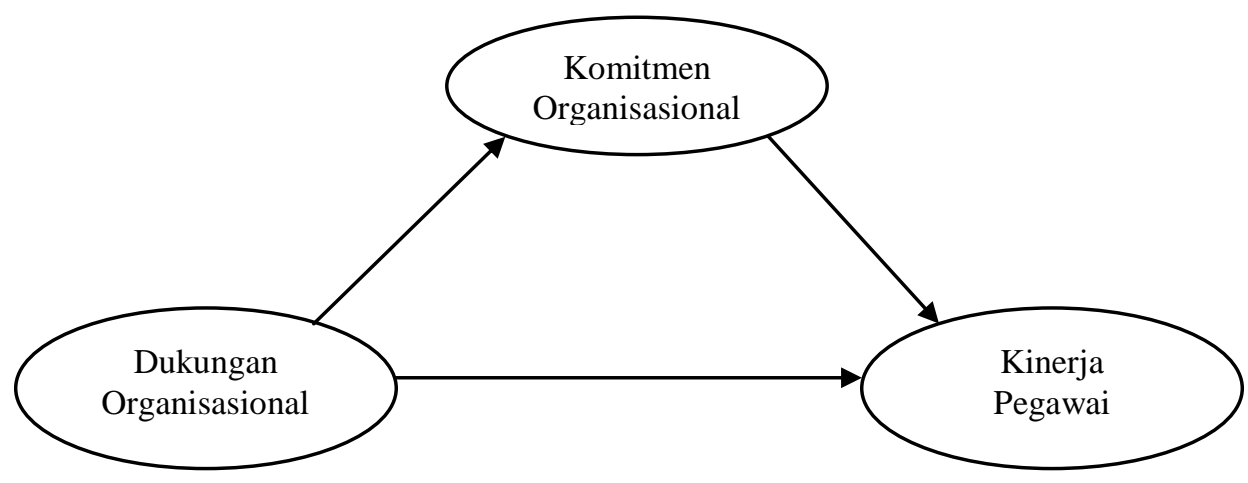

Gambar 1. Kerangka Konseptual Penelitian 


\section{METODE PENELITIAN}

Berdasarkan tingkat eksplanasinya, jenis penelitian ini merupakan penelitian asosiatif karena meneliti tentang pengaruh dukungan organisasi dan komitmen organisasional terhadap kinerja pegawai Dinas Kependudukan dan Pencatatan Sipil Kota Denpasar. Pada penelitian ini dilakukan pula penelahaan hubungan antara variabel yang berguna untuk mengukur hubungan antara riset atau untuk menganalisa bagaimana pengaruh suatu variabel terhadap variabel lainnya. Lokasi penelitian dilakukan di Dinas Kependudukan dan Pencatatan Sipil Kota Denpasar.

Penelitian ini menggunakan dua jenis data, yaitu data kuantitatif yang berupa data jumlah pegawai dan data dari skor total masing - masing variabel. Selanjutnya, data kualitatif berupa gambaran umum Dinas Kependudukan dan Pencatatan Sipil Kota Denpasar. Data yang digunakan dalam penelitian ini bersumber dari sumber primer yang diperoleh dari pegawai dari Dinas Kependudukan dan Pencatatan Sipil Kota Denpasar yang menjadi responden dan sumber sekunder diperoleh dari Dinas Kependudukan dan Pencatatan Sipil Kota Denpasar serta penelitian-penelitian terkait topik dukungan organisasi, komitmen organisasional, dan kinerja pegawai.

Populasi dalam penelitian ini adalah seluruh pegawai di Dinas Kependudukan dan Pencatatan Sipil Kota Denpasar baik yang bertatus Pegawai Negeri Sipil (PNS) maupun tenaga kontrak sebanyak 77 orang. Teknik pengambilan sampel yang digunakan adalah sampling jenuh. Sampling jenuh adalah teknik penentuan sampel bila semua anggota populasi digunakan sebagai sampel. Hal ini dilakukan karena jumlah populasi relatif kecil. Dengan demikian, 
jumlah sampel yang digunakan ditentukan sama dengan jumlah populasi yaitu 77 responden. Berikut pada Tabel 2 tersaji rinciannya.

Tabel 2. Rincian Jenis Jabatan Pegawai Dinas Kependudukan dan Pencatatan Sipil Kota Denpasar

\begin{tabular}{|c|c|c|c|}
\hline Jabatan & $\begin{array}{c}\text { Jumlah PNS } \\
\text { (orang) }\end{array}$ & $\begin{array}{c}\text { Jumlah Tenaga } \\
\text { Kontrak (orang) }\end{array}$ & $\begin{array}{c}\text { Jumlah Keseluruhan } \\
\text { (orang) }\end{array}$ \\
\hline Bidang Kependudukan & 19 & 32 & 51 \\
\hline Bidang Catatan Sipil & 12 & 14 & 26 \\
\hline Jumlah & $\mathbf{3 1}$ & $\mathbf{4 6}$ & $\mathbf{7 7}$ \\
\hline
\end{tabular}

Sumber: Dinas Kependudukan dan Pencatatan Sipil Kota Denpasar, 2017

Instrumen penelitian menggunakan kuesioner yang diberikan kepada pegawai Dinas Kependudukan dan Pencatatan Sipil Kota Denpasar. Skala pengukuran yang digunakan adalah Skala Likert 1 (Sangat Tidak Setuju) sampai 5 (Sangat Setuju). Pengukuran dukungan organisasi menggunakan dimensi dan indikator yang dikembangkan oleh Eisenberger et al. (1986). Pengukuran komitmen organisasional menggunakan dimensi dan indikator bersumber dari Allen dan Meyer (1997). Pengukuran variabel kinerja pegawai menggunakan dimensi dan indikator yang diadopsi dari Miner dalam Sudarmanto (2009). Dalam proses pengumpulan data, kuesioner digunakan sebagai instrumen.

Data dikumpulkan dengan mengirimkan kuesioner yang diberikan secara pribadi. Setelah data diperoleh, maka selanjutnya dianalisis dengan statistik deskriptif untuk mengetahui karakteristik dan tanggapan responden terhadap itemitem pertanyaan pada kuesioner yang dijelaskan melalui tabel frekuensi yang menggambarkan distribusi jawaban responden untuk setiap indikator dan skor yang diperoleh. Analisis statistik inferensial menggunakan Partial Least Square 
(PLS), selanjutnya digunakan untuk menguji korelasi antar variabel yang digunakan dalam hipotesis.

\section{HASIL DAN PEMBAHASAN}

Berdasarkan hasil survei, responden didominasi oleh laki - laki sebanyak 40,3 persen, sedangkan sisanya perempuan sebesar 59,7 persen. Berdasarkan umur, responden yang berumur antara 31- 40 tahun adalah responden paling banyak dengan persentase sebesar 35,1 persen, kemudian berturut - turut diikuti oleh responden yang berumur diatas 40 tahun sebear 33,8 persen, responden yang berumur 21 - 30 dengan persentase sebesar 28,5 persen, sedangkan responden yang berumur di bawah 21 tahun merupakan jumlah responden terkecil dengan 2,6 persen

Lebih lanjut, dapat dilihat bahwa mayoritas pegawai Dinas Kependudukan dan Pencatatan Sipil Kota Denpasar adalah berpendidikan Strata 1 (S-1) sebesar 59,7 persen, disusul berturut-turut responden yang berpendidikan SMA/SMU sebesar 28,6 persen, Strata 2 (S-2) sebesar 7,8 persen, dan Diploma sebanyak 3,9 persen. Berdasarkan masa kerja, mayoritas responden memiliki masa kerja lebih dari 15 tahun yaitu sebesar 33,8 persen, kemudian diikuti oleh responden dengan masa kerja 6-15 tahun sebesar 27,2 persen, responden dengan masa kerja 3-5 tahun sebesar 20,8 persen, sedangkan sisanya yang memiliki masa kerja kurang dari 3 tahun sebesar 18,2 persen. 
Ketut Metria dan I Gede Riana. Pengaruh Dukungan Organisasi Terhadap Komitmen...

Tabel 3. Deskripsi Variabel Dukungan Organisasi

\begin{tabular}{|c|c|c|c|c|c|c|c|}
\hline \multirow{2}{*}{ Dimensi dan indikator } & \multicolumn{5}{|c|}{ Nilai Jawaban Responden } & \multirow{2}{*}{ Rerata } & \multirow{2}{*}{ Kriteria } \\
\hline & 1 & 2 & 3 & 4 & 5 & & \\
\hline $\begin{array}{l}\text { Kepedulian organisasi terhadap kesejahteraan } \\
\text { pegawai (X1) }\end{array}$ & & & & & & 3.19 & Cukup \\
\hline $\begin{array}{l}\text { Organisasi benar-benar peduli terhadap } \\
\text { kesejahteraan saya }(\mathrm{X} 1.1)\end{array}$ & 0 & 6 & 19 & 48 & 4 & 3.65 & Baik \\
\hline $\begin{array}{l}\text { Organisasi mengabaikan kepentingan saya, ketika } \\
\text { membuat keputusan yang mempengaruhi saya } \\
\text { (X1.2) }\end{array}$ & 4 & 28 & 30 & 14 & 1 & 2.74 & Cukup \\
\hline $\begin{array}{l}\text { Kepedulian organisasi terhadap kepuasan } \\
\text { pegawai (X2) }\end{array}$ & & & & & & 3.76 & Baik \\
\hline $\begin{array}{l}\text { Atasan saya bangga karena saya menjadi bagian } \\
\text { dari organisasi ini (X2.1) }\end{array}$ & 0 & 8 & 10 & 54 & 5 & 3.72 & Baik \\
\hline $\begin{array}{l}\begin{array}{l}\text { Organisasi menghargai kontribusi yang } \\
\text { berikan (X2.2) }\end{array} \\
\end{array}$ & 1 & 2 & 11 & 60 & 3 & 3.80 & Baik \\
\hline $\begin{array}{l}\text { Kepedulian organisasi terhadap pendapat } \\
\text { pegawai (X3) }\end{array}$ & & & & & & 3.72 & Baik \\
\hline $\begin{array}{l}\text { Organisasi sangat mempertimbangkan apa yang } \\
\text { menjadi tujuan saya (X3.1) }\end{array}$ & 0 & 4 & 21 & 48 & 4 & 3.68 & Baik \\
\hline Organisasi peduli terhadap pendapat saya (X3.2) & 0 & 1 & 18 & 56 & 2 & 3.76 & Baik \\
\hline $\begin{array}{l}\text { Kepedulian organisasi terhadap masalah yang } \\
\text { dihadapi pegawai (X4) }\end{array}$ & & & & & & 3.96 & Baik \\
\hline $\begin{array}{l}\text { Organisasi bersedia membantu saya untuk } \\
\text { melakukan pekerjaan yang terbaik sesuai dengan } \\
\text { kemampuan saya }(\mathrm{X} 4.1)\end{array}$ & 0 & 1 & 4 & 52 & 20 & 4.18 & Baik \\
\hline Organisasi menanggapi keluhan saya (X4.2) & 0 & 3 & 22 & 45 & 7 & 3.73 & Baik \\
\hline $\begin{array}{l}\text { Organisasi memberikan bantuan ketika saya } \\
\text { mengalami masalah (X4.3) }\end{array}$ & 0 & 3 & 5 & 60 & 9 & 3.97 & Baik \\
\hline $\begin{array}{l}\text { Kepedulian organisasi terhadap kerja keras } \\
\text { pegawai (X5) }\end{array}$ & & & & & & 3.57 & Baik \\
\hline $\begin{array}{l}\text { Organisasi kurang menghargai kerja keras yang } \\
\text { saya lakukan untuk kemajuan organisasi (X5.1) }\end{array}$ & 3 & 11 & 40 & 21 & 2 & 3.10 & Cukup \\
\hline $\begin{array}{lccc}\begin{array}{l}\text { Organisasi } \\
\text { berhasil dalam pekerjaan saya }\end{array} & \text { (X5.2) }\end{array}$ & 0 & 0 & 10 & 54 & 13 & 4.04 & Baik \\
\hline $\begin{array}{l}\text { Kepedulian organisasi terhadap peningkatan } \\
\text { kinerja pegawai (X6) }\end{array}$ & & & & & & 3.83 & Baik \\
\hline $\begin{array}{l}\text { Organisasi menghargai kontribusi saya } \text { untuk } \\
\text { kesuksesan organisasi (X6.1) }\end{array}$ & 0 & 1 & 11 & 62 & 3 & 3.87 & Baik \\
\hline $\begin{array}{l}\text { Organisasi bangga akan prestasi saya di tempat kerja } \\
\text { (X6.2) }\end{array}$ & 0 & 1 & 16 & 57 & 3 & 3.81 & Baik \\
\hline $\begin{array}{l}\text { Organisasi merasa bahwa siapapun bisa melakukan } \\
\text { pekerjaan seperti apa yang saya lakukan (X6.3) }\end{array}$ & 0 & 3 & 18 & 47 & 9 & 3.81 & Baik \\
\hline Rata - Rata Variabel Dukungan Organisasi $(\mathrm{X})$ & & & & & & 3.67 & Baik \\
\hline
\end{tabular}

Sumber: Hasil penelitian, 2017

Pada Tabel 3, menunjukkan bahwa indikator pertanyaan organisasi mengabaikan kepentingan saya, ketika membuat keputusan yang mempengaruhi saya memiliki nilai terendah dengan pertimbangan persepsi rerata (mean) yang 
diperoleh sebesar 2,74. hal ini menunjukkan organisasi kurang memfasilitasi permasalahan yang dihadapi karyawan, dan keputusan mutlak ada pada pimpinan.

Pernyataan responden mengenai organisasi bersedia membantu saya untuk melakukan pekerjaan yang terbaik sesuai dengan kemampuan saya memiliki nilai tertinggi dengan pertimbangan persepsi rerata (mean) sebesar 4,18, hal ini memiliki makna bahwa organisasi (pimpinan) sangat memperhatikan karyawan yang sungguh - sungguh bekerja sesuai kemampuannya dalam memberi pelayanan kepada masyarakat. Organisasi akan memberi reward kepada karyawan yang berprestasi dan akan memberi punishment kepada karyawan yang melakukan kesalahan.

Demikian pula berdasarkan dimensi dukungan organisasi, rerata terendah berada pada kepedulian organisasi terhadap kesejahteraan pegawai (3.19) dengan kreteria cukup, hal ini menunjukkan kesejahteraan pegawai belum memenuhi harapan yang dinginkan dan organisasi perlu memperhatikannya. Kesejahteraan merupakan faktor yang terpenting dan sangat diharapkan bagi setiap karyawan, karena bila kesejahteraan sudah terpenuhi maka kinerja karyawan juga meningkat sehingga tujuan organisasi akan lebih mudah tercapai. Dimensi tertinggi berada pada kepedulian organisasi terhadap masalah yang dihadapi pegawai (3.96), ini berarti karyawan sudah merasa diperhatikan terhadap setiap masalah yang dihadapinya. Kepedulian organisasi dalam hal ini seorang pimpinan melihat apabila setiap permasalahan yang dihadapi karyawan dibiarkan akan menjadi kendala yang serius terhadap kinerja pegawai yang nantinya bisa mengganggu dalam memberikan pelayanan kepada masyarakat. Selanjutnya berturut - berturut 
kepedulian organisasi terhadap peningkatan kinerja pegawai $(3,83)$, kepedulian organisasi terhadap kepuasan pegawai $(3,76)$, kepedulian organisasi terhadap pendapat pegawai $(3,72)$, dan kepedulian organisasi terhadap kerja keras pegawai $(3,57)$, Secara keseluruhan tanggapan responden terhadap dukungan organisasi dinyatakan baik $(3,67)$. Artinya dukungan dari organisasi dalam hal ini pimpinan sudah merespon apa yang menjadi harapan dan keinginan karyawan, dimana karyawan sudah merasa diperhatikan kinerjanya, peduli terhadap masalah yang dihadapi karyawannya. Mau merespon dan menanggapi pendapat karyawan, menghargai kontribusi yang diberikan karyawan sehingga karyawan merasa nyaman dalam bekerja, walau di sisi lain kesejahteraan belum bisa memenuhi harapan yang diinginkan karyawan.

Pada Tabel 4, menunjukkan bahwa pertanyaan Saat ini bekerja di organisasi ini merupakan kebutuhan sekaligus juga keinginan saya dan Saya memiliki kepercayaan bahwa seseorang harus setia dengan organisasinya memiliki penilaian baik dengan pertimbangan persepsi rerata (mean) yang diperoleh sebesar 3,96 sebagai rerata tertinggi. Ini memiliki makna bahwa setiap karyawan memiliki pandangan untuk mencari pekerjaan saat ini sangat sulit sehingga begitu pekerjaan itu didapat maka karyawan akan setia pada organisasinya dan sulit untuk berpindah pekerjaan. Sedangkan pada pernyataan lainnya, yaitu pertanyaan Saya tidak percaya bahwa seseorang harus selalu loyal terhadap organisasinya memperoleh tanggapan terendah dengan nilai rerata sebesar 3,19. 
ISSN : 2337-3067

E-Jurnal Ekonomi dan Bisnis Universitas Udayana 7.9 (2018): 2117-2146

\section{Tabel 4. Deskripsi Variabel Komitmen Organisasional}

\begin{tabular}{|c|c|c|c|c|c|c|c|}
\hline \multirow{2}{*}{ Dimensi dan Indikator } & \multicolumn{5}{|c|}{ Nilai Jawaban Responden } & \multirow{2}{*}{ Rerata } & \multirow{2}{*}{ Kriteria } \\
\hline & 1 & 2 & 3 & 4 & 5 & & \\
\hline Affektive commitment(Y1.1) & & & & & & 3.80 & Baik \\
\hline $\begin{array}{l}\text { Saya benar-benar merasakan bahwa masalah } \\
\text { organisasi ini adalah masalah saya juga(Y1.1.1) }\end{array}$ & 0 & 0 & 15 & 55 & 7 & 3.89 & Baik \\
\hline $\begin{array}{l}\text { Saya merasa bahagia untuk menghabiskan waktu } \\
\text { saya berkarir dalam organisasi ini(Y1.1.2) }\end{array}$ & 1 & 2 & 15 & 52 & 7 & 3.80 & Baik \\
\hline $\begin{array}{l}\text { Saya merasa terikat secara emosional dengan } \\
\text { organisasi(Y1.1.3) }\end{array}$ & 1 & 2 & 19 & 52 & 3 & 3.70 & Baik \\
\hline Continuance commitment(Y1.2) & & & & & & 3.69 & Baik \\
\hline $\begin{array}{l}\text { Sangat sulit bagi saya meninggalkan organisasi ini } \\
\text { meskipun saya menginginkannya(Y1.2.1) }\end{array}$ & 0 & 5 & 29 & 35 & 8 & 3.58 & Baik \\
\hline $\begin{array}{l}\text { Saat ini bekerja di organisasi ini merupakan } \\
\text { kebutuhan sekaligus juga keinginan saya(Y1.2.2) }\end{array}$ & 0 & 1 & 13 & 51 & 12 & 3.96 & Baik \\
\hline $\begin{array}{l}\text { Banyak hal yang akan terganggu dalam kehidupan } \\
\text { saya, jika saya meninggalkan organisasi } \\
\text { ini(Y1.2.3) }\end{array}$ & 0 & 6 & 36 & 31 & 4 & 3.43 & Baik \\
\hline $\begin{array}{l}\text { Sekarang ini tetap bertahan menjadi anggota } \\
\text { organisasi ini adalah hal yang sesuai dengan } \\
\text { keinginan saya(Y1.2.4) }\end{array}$ & 0 & 4 & 12 & 55 & 6 & 3.82 & Baik \\
\hline Normative commitment $(\mathbf{Y} 1.3)$ & & & & & & 3.45 & Baik \\
\hline $\begin{array}{l}\text { Saya tidak percaya bahwa seseorang harus selalu } \\
\text { loyal terhadap organisasinya(Y1.3.1) }\end{array}$ & 3 & 9 & 37 & 26 & 2 & 3.19 & Cukup \\
\hline $\begin{array}{l}\text { Berpindah dari satu organisasi ke organisasi lain } \\
\text { merupakan suatu hal yang tidak etis bagi } \\
\text { saya(Y1.3.2) }\end{array}$ & 0 & 9 & 41 & 21 & 6 & 3.31 & Cukup \\
\hline $\begin{array}{l}\text { Saya memiliki kepercayaan bahwa seseorang harus } \\
\text { setia dengan organisasinya(Y1.3.3) }\end{array}$ & 0 & 1 & 10 & 57 & 9 & 3.96 & Baik \\
\hline $\begin{array}{l}\text { Menurut saya yang lebih baik saat ini adalah ketika } \\
\text { orang tetap bekerja di satu organisasi sepanjang } \\
\text { karir mereka(Y1.3.4) }\end{array}$ & 1 & 10 & 31 & 32 & 3 & 3.34 & Cukup \\
\hline $\begin{array}{l}\text { Rata-rata Variabel Komitmen Organisasional } \\
\left(\mathbf{Y}_{1}\right)\end{array}$ & & & & & & 3.64 & Baik \\
\hline
\end{tabular}

Sumber: Hasil penelitian, 2017

Secara keseluruhan rata - rata variabel komitmen organisasional dapat dikatagorikan baik $(3,64)$. Apabila dilihat dari masing - masing dimensi, maka dimensi affective commitment memiliki nilai tertinggi yaitu 3,80 ini mengindikasikan bahwa karyawan memiliki hubungan emosional dengan organisasinya dan akan terus menjadi anggota organisasi. continuance commitment 3,69 yang mengindikasikan kesadaran anggota organisasi/karyawan 
Ketut Metria dan I Gede Riana. Pengaruh Dukungan Organisasi Terhadap Komitmen...

untuk tetap menjadi karyawan karena mereka merasa memiliki kebutuhan dan mengalami kerugian jika meninggalkan organisasi, dan normative commitment memiliki nilai terendah sebesar 3,45. hal ini mengindikasikan bahwa karyawan merasa kesulitan untuk mencari pekerjaan lain bila meninggalkan organisasinya meskipun perlakuan pimpinan terhadap karyawan yang memiliki kinerja baik dengan yang berkinerja buruk di hargai sama.

Tabel 5. Deskripsi Variabel Kinerja Pegawai

\begin{tabular}{|c|c|c|c|c|c|c|c|}
\hline \multirow{2}{*}{ Dimensi dan Indikator } & \multicolumn{5}{|c|}{ Nilai Jawaban Responden } & \multirow{2}{*}{ Rerata } & \multirow{2}{*}{ Kriteria } \\
\hline & 1 & 2 & 3 & 4 & 5 & & \\
\hline Kualitas (Y2.1) & & & & & & 4.22 & Baik \\
\hline Saya melakukan pekerjaan dengan teliti (Y2.1.1) & $\mathbf{0}$ & $\mathbf{0}$ & $\mathbf{0}$ & 60 & 17 & 4.22 & Baik \\
\hline $\begin{array}{l}\text { Saya melakukan pekerjaan sesuai dengan standar } \\
\text { operating procedure (SOP) yang ada (Y2.1.2) }\end{array}$ & 0 & 0 & 2 & 47 & 28 & 4.34 & $\begin{array}{c}\text { Sangat } \\
\text { Baik }\end{array}$ \\
\hline $\begin{array}{l}\text { Saya memberikan hasil pekerjaan yang berharga } \\
\text { bagi organisasi (Y2.1.3) }\end{array}$ & 0 & 0 & 5 & 53 & 19 & 4.18 & Baik \\
\hline $\begin{array}{l}\text { Tingkat kesalahan dari hasil pekerjaan dapat saya } \\
\text { kurangi dari waktu ke waktu (Y2.1.4) }\end{array}$ & 0 & 0 & 4 & 58 & 15 & 4.14 & Baik \\
\hline Kuantitas (Y2.2) & & & & & & 4.08 & Baik \\
\hline $\begin{array}{l}\text { Saya memahami cara untuk mencapai hasil yang } \\
\text { diinginkan organisasi (Y2.2.1) }\end{array}$ & 0 & 0 & 5 & 59 & 13 & 4.10 & Baik \\
\hline $\begin{array}{l}\text { Hasil pekerjaan saya selama ini telah sesuai dengan } \\
\text { tujuan yang diharapkan organisasi (Y2.2.2) }\end{array}$ & 0 & 0 & $\begin{array}{l}1 \\
1\end{array}$ & 50 & 16 & 4.07 & Baik \\
\hline Penggunaan waktu dalam bekerja (Y2.3) & & & & & & 4.23 & Baik \\
\hline $\begin{array}{l}\text { Saya menyelesaikan pekerjaan dengan tepat waktu } \\
\text { (Y2.3.1) }\end{array}$ & 0 & 0 & 5 & 53 & 19 & 4.18 & Baik \\
\hline $\begin{array}{l}\text { Saya mengetahui waktu kerja yang sesuai dengan } \\
\text { standar kerja yang ada (Y2.3.2) }\end{array}$ & 0 & 0 & 1 & 55 & 21 & 4.26 & $\begin{array}{c}\text { Sangat } \\
\text { Baik }\end{array}$ \\
\hline $\begin{array}{l}\text { Saya tidak pernah menunda-nunda waktu dalam } \\
\text { menyelesaikan Pekerjaan (Y2.3.3) }\end{array}$ & 0 & 0 & 0 & 56 & 21 & 4.27 & $\begin{array}{c}\text { Sangat } \\
\text { Baik }\end{array}$ \\
\hline $\begin{array}{l}\text { Saya memiliki tingkat disiplin kehadiran yang tinggi } \\
\text { (Y2.3.4) }\end{array}$ & 0 & 0 & 6 & 50 & 21 & 4.19 & Baik \\
\hline Kerjasama dengan orang lain (Y2.4) & & & & & & 4.38 & $\begin{array}{c}\text { Sangat } \\
\text { Baik }\end{array}$ \\
\hline $\begin{array}{l}\text { saya sering mengutamakan kerjasama dengan rekan } \\
\text { kerja dalam menyelesaikan pekerjaan (Y2.4.1) }\end{array}$ & 0 & 0 & 0 & 44 & 33 & 4.43 & $\begin{array}{c}\text { Sangat } \\
\text { Baik }\end{array}$ \\
\hline $\begin{array}{l}\text { Saya memiliki kesadaran untuk bekerjasama dalam } \\
\text { mencapai tujuan organisasi (Y2.4.2) }\end{array}$ & 0 & 0 & 2 & 46 & 29 & 4.35 & $\begin{array}{c}\text { Sangat } \\
\text { Baik }\end{array}$ \\
\hline $\begin{array}{l}\text { Saya memiliki kemampuan untuk bekerja dalam tim } \\
\text { (Y2.4.3) }\end{array}$ & 0 & 1 & 1 & 43 & 32 & 4.38 & $\begin{array}{c}\text { Sangat } \\
\text { Baik }\end{array}$ \\
\hline $\begin{array}{l}\text { Saya memiliki keterbukaan dalam menyampaikan } \\
\text { atau menerima pendapat rekan kerja (Y2.4.4) }\end{array}$ & 0 & 0 & 2 & 46 & 29 & 4.35 & $\begin{array}{c}\text { Sangat } \\
\text { Baik }\end{array}$ \\
\hline Kinerja Pegawai (Y2) & & & & & & 4.23 & Baik \\
\hline
\end{tabular}

Sumber: Hasil penelitian, 2017 
Tabel 5 menunjukkan bahwa saya sering mengutamakan kerjasama dengan rekan kerja dalam menyelesaikan pekerjaan mendapat penilaian paling tinggi, ini berdasarkan pertimbangan persepsi rerata (mean) sebesar 4,43. Selanjutnya bahwa pertanyaan hasil pekerjaan saya selama ini telah sesuai dengan tujuan yang diharapkan organisasi memperoleh penilaian terkecil dengan nilai rerata sebesar 4,07. Berdasarkan hasil analisis deskriptif terhadap kinerja pegawai, secara umum dapat dinyatakan bahwa kinerja pegawai dinyatakan baik dengan rata rata 4,23 .

Data selanjutnya dianalisis menggunakan Partial Least Square (PLS). Terdapat dua evaluasi model mendasar dalam pengujian ini yaitu outer model dan inner model. Seperti yang tersaji pada Tabel 6, uji outer model ada tiga tahapan yaitu convergent validity, discriminant validity, dan composite reliability.

Tabel 6. Uji Outer Model

\begin{tabular}{|c|c|c|c|c|}
\hline Variabel dan Indikatornya & $\begin{array}{c}\text { Outer } \\
\text { Loadings } *)\end{array}$ & AVE *) & $\begin{array}{c}\text { Composite } \\
\text { Reliability **) }\end{array}$ & Cronbach Alpha **) \\
\hline \multicolumn{5}{|l|}{ Dukungan Organisasi $(\mathrm{X})$} \\
\hline $\mathrm{X} 1$ & 0,554 & \multirow{6}{*}{0,517} & \multirow{6}{*}{0,862} & \multirow{6}{*}{0,809} \\
\hline $\mathrm{X} 2$ & 0,559 & & & \\
\hline $\mathrm{X} 3$ & 0,836 & & & \\
\hline $\mathrm{X} 4$ & 0,836 & & & \\
\hline $\mathrm{X} 5$ & 0,666 & & & \\
\hline X6 & 0,801 & & & \\
\hline \multicolumn{5}{|c|}{ Komitmen Organisasional (Y1) } \\
\hline Y1.1 & 0,764 & \multirow{3}{*}{0,643} & \multirow{3}{*}{0,969} & \multirow{3}{*}{0,957} \\
\hline Y1.2 & 0,898 & & & \\
\hline Y1.3 & 0,734 & & & \\
\hline \multicolumn{5}{|l|}{ Kinerja Pegawai (Y2) } \\
\hline Y2.1 & 0,949 & \multirow{4}{*}{0,887} & \multirow{4}{*}{0,843} & \multirow{4}{*}{0,720} \\
\hline Y2.2 & 0,933 & & & \\
\hline Y2.3 & 0,947 & & & \\
\hline Y2.4 & 0,937 & & & \\
\hline
\end{tabular}

Catatan: *) indikator valid apabila outer loadings dan AVE > 0,50

**) indikator reliabel apabila composite reliability dan cronbach alpha $>0,70$

Sumber: Hasil penelitian, 2017 
Pengujian inner model dilakukan dengan melihat nilai $R$-square. Berdasarkan Tabel 7, model pengaruh dukungan organisasi terhadap komitmen organisasional memberikan nilai $R$-square sebesar 0,403 yang dapat diinterpretasikan bahwa variabilitas variabel komitmen organisasional dapat dijelaskan oleh variabilitas variabel dukungan organisasi sebesar 40,3 persen, sedangkan 59,7 persen dijelaskan oleh variabel lain diluar yang diteliti. Selanjutnya, model pengaruh dukungan organisasi dan komitmen organisasional terhadap kinerja pegawai memberikan nilai $R$-square sebesar 0,463 yang dapat diinterpretasikan bahwa variabilitas variabel kinerja pegawai dapat dijelaskan oleh variabilitas variabel dukungan organisasi dan komitmen organisasional sebesar 46,3 persen, sedangkan 53,7 persen dijelaskan oleh variabel lain diluar yang diteliti.

Tabel 7. R-Square

\begin{tabular}{|c|c|}
\hline Variabel & $R$-square \\
\hline Komitmen organisasional (Y1) & 0,403 \\
\hline Kinerja pegawai (Y2) & 0,462 \\
\hline \multicolumn{2}{|l|}{ Sumber: Hasil penelitian, 2017} \\
\hline \multicolumn{2}{|c|}{ Untuk mengukur seberapa baik nilai observasi dihasilkan oleh model dan } \\
\hline \multicolumn{2}{|c|}{ juga estimasi parameternya, maka perlu menghitung $Q$-square sebagai berikut: } \\
\hline \multicolumn{2}{|l|}{$\mathrm{Q}^{2}=1-\left(1-\left(\mathrm{R}_{1}\right)^{2}\right)\left(1-\left(\mathrm{R}_{2}\right)^{2}\right)$} \\
\hline \multicolumn{2}{|l|}{$=1-(1-0,403)(1-0,462)$} \\
\hline \multicolumn{2}{|l|}{$=1-(0,597)(0,538)$} \\
\hline \multicolumn{2}{|l|}{$=1-0,321$} \\
\hline$=0,679$ & \\
\hline
\end{tabular}


Besaran $\mathrm{Q}^{2}$ memiliki nilai dengan rentang $0<\mathrm{Q}^{2}<1$, dimana semakin mendekati 1 berarti model semakin baik. Hasil perhitungan tersebut didapat nilai $\mathrm{Q}^{2}$ adalah sebesar 0,679 , sehingga dapat disimpulkan bahwa model memiliki predictive relevance yang baik. Dengan demikian, dapat dijelaskan bahwa 67,9 persen variasi pada kinerja pegawai dipengaruhi oleh dukungan organisasi dan komitmen organisasional, sedangkan 32,1 persen dipengaruhi oleh variabel lain.

Tabel 8. Koefisien Path

\begin{tabular}{|c|c|c|c|}
\hline Koefisien Path Antar Variabel & Koefisien Jalur & t Statistics & Keterangan \\
\hline $\begin{array}{lll}\text { Dukungan organisasi } & (\mathrm{X}) \rightarrow & \text { Kinerja } \\
\text { pegawai (Y2) } & & \end{array}$ & 0,389 & 4,086 & Signifikan \\
\hline $\begin{array}{l}\text { Dukungan organisasi }(\mathrm{X}) \rightarrow \text { Komitmen } \\
\text { organisasional (Y1) }\end{array}$ & 0,634 & 9,091 & Signifikan \\
\hline $\begin{array}{l}\text { Komitmen organisasional }(\mathrm{Y} 1) \rightarrow \text { Kinerja } \\
\text { pegawai (Y2) }\end{array}$ & 0,363 & 4,635 & Signifikan \\
\hline
\end{tabular}

Sumber: Hasil penelitian, 2017

Tabel 8 menunjukkan bahwa pengujian hipotesis pada pengaruh dukungan organisasi terhadap kinerja pegawai menghasilkan nilai koefisien korelasi sebesar 0,389. Nilai $t$ Statistics didapat sebesar 4,086 (> t kritis 1,96), maka pengaruh dukungan organisasi terhadap kinerja pegawai adalah signifikan. Dengan demikian, maka hipotesis $1\left(\mathrm{H}_{1}\right)$ yang menyatakan bahwa dukungan organisasi berpengaruh positif dan signifikan terhadap kinerja pegawai diterima.

Hal ini menjelaskan bahwa dukungan organisasi dicerminkan pada kepedulian organisasi terhadap kepuasan pegawai melalui penghargaan organisasi pada kontribusi yang diberikan pegawai, kepedulian terhadap pendapat melalui 
rasa peduli organisasi terhadap segala aspirasi yang diberikan oleh pegawai, kepedulian terhadap masalah yang dihadapi melalui kesediaan untuk membantu dalam menempatkan pegawai pada pekerjaan yang tepat sesuai dengan kemampuannya dan memberi bantuan ketika mendapat masalah, kepedulian terhadap peningkatan kinerja melalui penghargaan atas kontribusi yang diberikan. Dukungan organisasi akan berdampak pada kinerja pegawai yang tercermin melalui. Ini menunjukkan bahwa kinerja pegawai yang dicerminkan melalui penggunaan waktu dalam bekerja melalui kesesuaian antara waktu kerja dengan standar kerja dan tidak pernah menunda-nunda waktu dalam melaksanakan pekerjaan.

Hasil penelitian ini sesuai dengan temuan-temuan penelitian sebelumnya yang dilakukan oleh Eisenberger et al. (1986), Odunlami et al. (2014), Arshadi et al. (2013) dan Susmiati (2015), Afzali et al. (2014), Silviana Mursidta (2017) membuktikan hal yang sama dimana peran dukungan organisasi berdampak positif secara langsung berpengaruh terhadap kinerja pegawai sehingga memberikan hasil positif terhadap kinerja instansi.

Tabel 8 menunjukkan bahwa pengujian hipotesis pada pengaruh dukungan organisasi terhadap komitmen organisasional menghasilkan nilai koefisien korelasi sebesar 0,634. Nilai $t$ Statistics didapat sebesar 9,091 (> t kritis 1,96), maka pengaruh dukungan organisasi terhadap komitmen organisasional adalah signifikan. Dengan demikian, maka hipotesis $2\left(\mathrm{H}_{2}\right)$ yang menyatakan bahwa dukungan organisasi berpengaruh positif dan signifikan terhadap komitmen organisasional diterima. 
Dukungan organisasi dicerminkan pada kepedulian organisasi terhadap kepuasan pegawai melalui penghargaan organisasi pada kontribusi yang diberikan pegawai, kepedulian terhadap pendapat melalui rasa peduli organisasi terhadap segala aspirasi yang diberikan oleh pegawai, kepedulian terhadap masalah yang dihadapi melalui kesediaan untuk membantu dalam menempatkan pegawai pada pekerjaan yang tepat sesuai dengan kemampuannya dan memberi bantuan ketika mendapat masalah, kepedulian terhadap peningkatan kinerja melalui penghargaan atas kontribusi yang diberikan. Hal tersebut selanjutnya berdampak pada komitmen organisasional yang ditunjukkan pada continuance commitment dan affective commitment yang ditemukan memiliki nilai diatas rata-rata variabel komitmen organisasional. Ini menunjukkan bahwa komitmen organisasional yang dicerminkan melalui affective commitment melalui perasaaan bahwa masalah organisasi merupakan masalah mereka juga. Selanjutnya, komitmen organisasional dicerminkan melalui continuance commitment melalui perasaaan sulit untuk meninggalkan organisasi, perasaaan ketergantungan dan membutuhkan organisasi sebagai tempat untuk bekerja, serta keinginan untuk bertahan di organisasi.

Hasil penelitian ini sejalan dengan hasil penelitian sebelumnya yang dilakukan oleh Blau dalam Chiang et al. (2011), Tumwesigye (2010), Wahyu (2011), Aube et al. (2007), Gupta et al. (2010), Dewi dan Rahyuda (2015), Adhika dan Riana (2016) membuktikan hal yang sama bahwa, semakin baik dukungan organisasional yang dirasakan karyawan, komitmen organisasional akan meningkat. 
Hasil analisis seperti yang tersaji pada Tabel 8, menunjukkan bahwa pengujian hipotesis pada pengaruh komitmen organisasional terhadap kinerja pegawai menghasilkan nilai koefisien korelasi sebesar 0,363. Nilai $t$ Statistics didapat sebesar 4,635 (> t kritis 1,96), maka pengaruh komitmen organisasional terhadap kinerja pegawai adalah signifikan. Dengan demikian, maka hipotesis 3 $\left(\mathrm{H}_{3}\right)$ yang menyatakan bahwa komitmen organisasional berpengaruh positif dan signifikan terhadap kinerja pegawai diterima.

Continuance commitment dan affective commitment ditemukan memiliki nilai diatas rata-rata variabel komitmen organisasional. Ini menunjukkan bahwa komitmen organisasional yang dicerminkan melalui affective commitment melalui perasaaan bahwa masalah organisasi merupakan masalah mereka juga. Selanjutnya, komitmen organisasional dicerminkan melalui continuance commitment melalui perasaaan sulit untuk meninggalkan organisasi, perasaaan ketergantungan dan membutuhkan organisasi sebagai tempat untuk bekerja, serta keinginan untuk bertahan di organisasi. Hal ini akan berdampak pada kinerja pegawai yang ditunjukkan dari penggunaan waktu dalam bekerja, yang ditemukan memiliki nilai diatas rata-rata variabel kinerja pegawai. Ini menunjukkan bahwa kinerja pegawai yang dicerminkan melalui penggunaan waktu dalam bekerja melalui kesesuaian antara waktu kerja dengan standar kerja dan tidak pernah menunda-nunda waktu dalam melaksanakan pekerjaan.

Hasil penelitian ini sejalan dengan hasil penelitian sebelumnya yang dilakukan oleh Becker et al. (1996), Meyer et al. (2002), Chen dan Francesco (2003), Lotunani et al. (2014), Wibowo (2014), Irefin dan Mechanic (2014), 
Lotunani et al. (2014), Murgianto et al. (2016) yang menyimpulkan bahwa komitmen organisasional berpengaruh positif dan signifikan terhadap kinerja.

\section{SIMPULAN DAN SARAN}

Berdasarkan hasil pembahasan, maka dapat disimpulkan bahwa, pertama, dukungan organisasi berpengaruh positif signifikan terhadap kinerja pegawai. Hal ini mengandung makna bahwa dukungan organisasi yang baik, akan dapat meningkatkan kinerja pegawai. Kedua, dukungan organisasi berpengaruh positif signifikan terhadap komitmen organisasional. Hal ini mengandung makna bahwa, semakin kuat dukungan organisasi maka semakin tinggi pula komitmen organisasional pegawainya. Ketiga, komitmen organisasional berpengaruh positif signifikan terhadap kinerja pegawai. Hal ini mengandung makna bahwa, semakin tinggi komitmen organisasional pegawai maka kinerja pegawai akan semakin meningkat.

Berdasarkan hasil penelitian, terdapat juga beberapa saran untuk meningkatkan kinerja pegawai melalui dukungan organisasi dan komitmen organisasional yaitu, pertama, instansi harus dapat lebih memberi dukungan kepada karyawannya, dimana kesejahteraan karyawan perlu ditingkatkan untuk lebih meningkatkan kinerja dalam menyelesaikan pekerjaan yang telah dipersepsikan baik oleh karyawan agar pegawai tersebut mempunyai rasa keyakinan bahwa mereka merupakan bagian dari instansi.

Rendahnya dukungan organisasi ditunjukkan pada kurangnya kepedulian organisasi terhadap kesejahteraan pegawai dan kepedulian terhadap kerja keras pegawai. Hal yang dapat disarankan untuk organisasi adalah dengan 
meningkatkan kesadaran organisasi akan pentingnya memperhatikan kepentingan pegawai dalam menentukan kebijakan yang dapat mempengaruhi mereka. Selain itu organisasi juga perlu meningkatkan penghargaan bagi pegawai yang telah bekerja keras demi kemajuan organisasi.

Kedua, membangun komitmen pegawai dengan meningkatkan moral dan loyalitas pegawai yang didasarkan pada perasaan wajib dan tanggungjawab pada instansi yang mempekerjakannya. Rendahnya komitmen organisasional ditunjukkan pada rendahnya normative commitment. Hal yang dapat disarankan untuk organisasi adalah dengan meningkatkan loyalitas pegawai terhadap organisasi dengan cara memberikan reward atau penghargaan yang sesuai dengan hasil kerjanya. Selanjutnya, menekan keinginan pegawai untuk berpindah dari satu organisasi ke organisasi lain dan meningkatkan keyakinan mereka untuk berkarir lebih lama di organisasi. Ini dapat dilakukan dengan menyadarkan pegawai akan keuntungan bekerja di Dinas Kependudukan dan Pencatatan Sipil Kota Denpasar.

Ketiga, mempertahankan dan meningkatkan kinerja pegawai dengan selalu memberi perhatian pada kualitas, kuantitas, penggunaan waktu dalam bekerja dan selalu menjaga kerjasama tim dalam menghadapi segala permasalahan yang dihadapi dalam melaksanakan tugas sebagai pelayan masyarakat. Rendahnya kinerja pegawai ditunjukkan pada rendahnya kualitas dan kuantitas kerja. Hal yang dapat disarankan untuk organisasi adalah organisasi perlu menekan tingkat kesalahan yang dapat dilakukan pegawai saat bekerja. Ini dapat dilakukan dengan membenahi cara kerja pegawai dan mengevaluasi secara berkala. Selain itu, 
organisasi juga perlu meningkatkan kuantitas hasil kerja agar sesuai dengan target yang telah ditetapkan.

\section{REFERENSI}

Adhika, R. dan Riana, I.G. 2016. Pengaruh Dukungan Organisasional dan Kepuasan Kerja terhadap Komitmen Karyawan, E-Jurnal Ekonomi dan Bisnis Universitas Udayana $5.4: 857-876$

Afzali, A., Amir A.M, Loghman, H.S. 2014. "Investigating The Influence Of Perceived Organizational Support, Psychological Empowerment And Organizational Learning On Job Performance: An Empirical Investigation. Tehnički vjesnik. Vol. $3(21): p p$ 623-629.

Aube, C., Rousseau, V., and Morin, E.M. 2007. Perceived Organizational Support and Organizational Commitment: The Moderating Effect of Locus Of Control and Work Autonomy. Journal of Managerial Psychology, 22(5): 479-495.

Arshadi, Nasrin, Ghazal Hayavi. 2013. "The Effect of Perceived Organizational Support on Affective Commitment and Job Performance: Mediating role of OBSE". Procedia - Social and Behavioral Sciences (84) : pp 739 - 743

Becker, T.E., Billings, R.S., Eveleth, D.M., and Gilbert, N.L. 1996. Foci and bases of employee commitment: implications for job performance. Academy of Management Journal, 39(2): 464 -482.

Celep, C. and Yilmazturk. O.E. 2012. The relationship among organizational trust, multidimensional organizational commitment and perceived organizational support in educational organizations.Procedia - Social and Behaviour Sciences, Vol 46, pp. $5763-5776$.

Chen, Z. X and Francesco, A. M. 2003.The Relationship Between the Three Components of Commitment and Employee Performance in China. Journal of Vocational Behavior.Vol. 62, No. 3, pp: 90-510.

Chiang, Hsu, and Hsin. 2011. The Relationship Between High-Commitment HRM and Knowledge Sharing Behavior and Its Mediators. International Journal of Manpower 32 (5-6):604-622 
Dewi, M. P. dan Rahyuda, A.G. 2015. Peran Pemediasian Komitmen Organisasi Pada Pengaruh Perceived Organizational Support Terhadap Intention To Leave, EJurnal Manajemen Unud, Vol. 4, No. 10, 2015: 2928 - 2954

Eisenberger, R., Hungtington, R., Hutchison, S., and Sowa, D. (1986).Perceived Organizational Support. Journal of Applied Psychology, 71, 500-507.

Eisenberger, R., Fasolo, P., and Davis-LaMastro, V., 1990, Perceived organizational support and employee diligence, commitment, and innovation, Journal of Applied Psychology, Vol.75, pp 51-59.

Eisenberger, R, and Rhoades, L. 2002. Perceived organizational support: A review of the literature. Journal of Applied Psychology, 87, 698-714.

Gupta, A. A., Vohra, N., and Bhatnagar, D. 2010. Perceived organizational support and Organizational Commitment. The Mediational Influence of Psychological WellBeing. Journal of Business and Management, 16(2): 105-124

Greenberg, J. 1996. Managing Behavior in Organizations: Science in Service to Practice. NY: Prentice Hall.

Gronroos. 1990. Service Management and Marketing: Managing the Moment of Truth in Service Competition, Lexington, MA: Lexington Books

Irefin, P., Mechanic, M.A. 2014. Effect of Employee Commitment on Organizational Performance In Coca Cola Nigeria Limited Maiduguri, Bromo State. IOSR Journal of Humanities and Social Science (IOSR-JHSS), 3(3): 33-41

Kumorotomo, W. 2005. Anggaran Berbasis Kinerja, Konsep dan Aplikasinya. Yogyakarta: MAP UGM

Lotunani, A., Idrus, M.S., Afnan, Setiawan, M. 2014. The Effect Of Competence On Perfomance, And Satisfaction With Reward As A Moderating Variable (A Study On Designing Work Plans In Kendari City Government Southeast Sulawesi), International Journal of Business And Management Invention, Vol. 3, Issue 2, pp. 18-25.

Mathis, R.L., dan Jackson, J.H. 2001. Manajemen Sumber Daya Manusia, Buku I .Jakarta : Salemba Empat.

Meglino, B.M and Ravlin, E.C, 1998, Individual Values in Organizations : Concepts, Controversies, and Research, Journal of management, University of South Carolina, Vol. 24, No.3, 351- 389

Meyer, J.P., and Allen, N.J. 1997.Commitment in the worplace theory research and application. California: Sage Publications. 
Meyer, J.P., Stanley, D.J., Herscovitch, L., and Topolnytsky, L. 2002. Affective, continuance and normative commitment to the organization: A meta-analysis of antecedents, correlates, and consequences. Journal of Vocational Behavior, 61, $20-52$.

Moenir. 1992. Sarana dan Prasaran. Tersedia: http://id.shvoong.com/writing-andspeaking/presenting/2106962-pengertian-sarana-dan prasarana /\#ixzz1K518G4nU, diakses pada tanggal 4 Juni 2017.

Mursidta, S. 2017. Pengaruh Perceived Organizational support (persepsi dukungan organisasi) dan Kepuasan Kerja terhadap Kinerja Karyawan pada PT. Varia Usaha Beton Gresik. Jurnal Ilmu Manajemen Vol. 5, No. 1

Murgianto, 2016. The Effect Of Commitmet, Competence, Work Satisfaction On Motivation and Performance of Employees At Integrated Service Office Of East Java. International Journal of Advanced Research.ISSN 2320-5407.

Nitisemito, A.S. 2000. Manajemen Personalia : Manajemen Sumber Daya Manusia, Edisi 3, Jakarta, Ghalia Indonesia.

Nunik R.H. 2001. Manajemen Pelayanan Publik Daerah, Dalam Manajemen Otonomi Daerah. Semarang: CLOGAPPS Universitas Diponegoro

Odunlami, I., Bolanle, A. and Oludele, M. 2014. Compensation Management and Employees Performance in the Manufacturing Sector, A Case Study of a Reputable Organization in the Food and Beverage Industry. International Journal of Managerial Studies and Research (IJMSR). 2(9). pp: 108- 117.

Rhoades, E. 2002. Perceived Suppervisor Support: Contributions to Perceived Organizational Support and Employee Retention. Journal of Applied Psychology, 87 (3): 565-571

Sudarmanto. 2009. Kinerja dan Pengembangan Kompetensi SDM (Teori, Dimensi Pengukuran dan Implementasi dalam Organisasi). Yogyakarta : Pustaka Pelajar

Susmiati dan Sudarma, K. 2015. "Pengaruh Budaya Organisasi Dan Dukungan Organisasi Persepsian Terhadap Kinerja Karyawan Dengan Komitmen Organisasi Sebagai Variabel Intervening”. Management Analysis Journal. Vol . 4 (1) : hal. 79-87.

Susskind, L., Levy F. P. and Thomas L. J. 2000 Negotiating Environmental Agreements. How to Avoid escalating Confrontation, Needless Costs and Unnecessary Litigation. Washington: Island Press.

Tumwesigye, G. 2010. The Relationship between perceived organisational support and Turnover Intentions in a developing country: the mediating role of organisational commitment. African Journal of Business Management, 4(6): 942-952 
Ketut Metria dan I Gede Riana. Pengaruh Dukungan Organisasi Terhadap Komitmen...

Wibowo. 2014. Manajemen Kinerja, Edisi keempat. Jakarta: Rajawali Pers. 